\title{
Changes with Time in the Availability of Soil Applied Zinc to Navy Beans and in the Chemical Extraction of Zinc from Soils
}

\author{
J. D. Armour; G. S. P. Ritchie and A. D. Robson
}

\begin{abstract}
The effect of the incubation of zinc $(\mathrm{Zn})$ applied to the soil on $\mathrm{Zn}$ uptake and the $\mathrm{Zn}$ concentrations in chemical extractants was studied. In a glasshouse experiment using a Zn-deficient gravelly sandy loam, the effect of recently applied $\mathrm{Zn}$ was compared with that of $\mathrm{Zn}$ incubated with the soil for 15 days at $40^{\circ} \mathrm{C}$ on growth and $\mathrm{Zn}$ uptake by navy beans (Phaseolus vulgaris cv. Gallaroy). At the second harvest ( 33 days after sowing), the dry weight of shoots of recently applied $\mathrm{Zn}$ was consistently higher than that of incubated $\mathrm{Zn}$, except at the highest rate of $1 \mu \mathrm{g} \mathrm{Zn}^{-1}$ soil, where yields were similar. Comparisons of the slope of the linear regressions of $\mathrm{Zn}$ uptake as a function of rate of application showed that incubated $\mathrm{Zn}$ was approximately $80 \%$ as effective as recently applied $\mathrm{Zn}$.

A laboratory experiment measured the decrease in $\mathrm{Zn}$ concentration in HCl, EDTA, DTPA, and dilute $\mathrm{CaCl}_{2}$ with incubation for up to 8 days at $40^{\circ} \mathrm{C}$ in four contrasting soils from Western Australia and Queensland. An addition of $2.5 \mu \mathrm{g} \mathrm{Zn} \mathrm{g}^{-1}$ soll increased the concentration of $\mathrm{Zn}$ in all extractants at all times of incubation compared with the untreated soil. The recovery of the added $\mathrm{Zn}$ was generally highest with $\mathrm{HCl}$ and lowest with $0.002 \mathrm{M} \mathrm{CaCl}_{2}$ and decreased exponentially in all extractants with increasing time of incubation in all soils. The order of the rate of decrease in $\mathrm{Zn}$ concentration for all extractants was krasnozem $>$ gravelly sandy loam $>$ sand $>$ sandy clay loam. The model, $Y=C t^{B}$, where $C$ and $B$ are constants, was used to describe the relationship between the recovery of added $\mathrm{Zn}$ and time of incubation.
\end{abstract}

\section{Introduction}

Zinc $(\mathrm{Zn})$ deficiency occurs in a variety of crops grown on a wide range of Australian soils (Donald and Prescott 1975). As a result, $\mathrm{Zn}$ is applied to large areas of soil to increase productivity of crops and pastures. Reactions of $\mathrm{Zn}$ with soil constituents appear to be the major factor determining decreases in availability of applied $\mathrm{Zn}$ to plants because losses of $\mathrm{Zn}$ by crop removal (Mengel and Kirkby 1978) and by leaching (Brennan and McGrath 1988) appear to be minor.

There is some evidence that $\mathrm{Zn}$ availability to plants decreases with time after application to the soil. Brennan and Gartrell (1986) reported that the yield of subterranean clover grown with $\mathrm{Zn}$ incubated for 30 days at $30^{\circ} \mathrm{C}$ was as low as $62 \%$ of that obtained with a fresh $\mathrm{Zn}$ application. Although incubation also reduced the concentration of $\mathrm{Zn}$ extracted from soils by DTPA, the changes in DTPA-extractable $\mathrm{Zn}$ were not always consistent with the yield of subterranean clover. 
Soil tests for $\mathrm{Zn}$ are one way of estimating its availability to plants and should help to predict the likelihood of a response to applied $\mathrm{Zn}$ before a crop is grown. Extractants with a wide soil : solution ratio and a high ionic strength, such as $0.1 \mathrm{M} \mathrm{HCl}$ (Trierweiler and Lindsay 1969), estimate quantity, while chelating agents such as DTPA are considered to measure both quantity and intensity (Lindsay and Norvell 1978). Extractants of neutral salts with low ionic strength such as $\mathrm{CaCl}_{2}$ will estimate intensity. Changes with time in the amount of $\mathrm{Zn}$ extracted must reflect changes in the availability of $\mathrm{Zn}$ for plant uptake.

The objectives of our study were to measure the effect of incubation of applied $\mathrm{Zn}$ on the availability of $\mathrm{Zn}$ to navy beans and on $\mathrm{Zn}$ extracted by $\mathrm{HCl}$, EDTA, DTPA and dilute $\mathrm{CaCl}_{2}$.

Table 1. Some properties of the soils used (air-dry basis, 0-10 cm)

\begin{tabular}{llllllllllr}
\hline Soil & $\begin{array}{c}\text { Loca- } \\
\text { tion }\end{array}$ & $\begin{array}{c}\text { Classif- } \\
\text { ication }\end{array}$ & $\mathrm{pH}^{\mathrm{C}}$ & $\begin{array}{c}\mathrm{OC}^{\mathrm{D}} \\
(\%)\end{array}$ & $\begin{array}{c}\mathrm{Fe} \\
(\%)\end{array}$ & $\begin{array}{c}\mathrm{Al} \\
(\%)\end{array}$ & $\begin{array}{c}\text { Sand } \\
(\%)\end{array}$ & $\begin{array}{c}\text { Silt } \\
(\%)\end{array}$ & $\begin{array}{c}\mathrm{Clay}^{\mathrm{E}} \\
(\%)\end{array}$ \\
\hline 1 & WH (W.A.) & UC5.22 & 6.2 & 0.5 & 0.02 & 0.02 & 92 & 1 & 8 \\
2 & Ta (W.A.) & Dy 3.81 & 6.5 & 3.0 & 0.05 & 0.43 & 79 & 6 & 15 \\
3 & M (W.A.) & Dr 2.33 & 6.9 & 1.6 & 0.03 & 0.06 & 72 & 7 & 21 \\
4 & T (Qld) & Gn 3.14 & 5.6 & 1.7 & 0.32 & 0.62 & 23 & 16 & 61 \\
\hline
\end{tabular}

A WH, Wongan Hills; Ta, Talbot; M, Merredin; T, Tolga.

B Northcote (1974).

C $1: 5 \mathrm{H}_{2} \mathrm{O}$.

D Organic carbon.

E Gee and Bauder (1986).

\section{Materials and Methods}

\section{Experiment 1. Effects of Incubation on Plant Growth}

The experiment was a complete factorial of six rates of $\mathrm{Zn}$ application and two times of $\mathrm{Zn}$ application with three replications. Navy beans (Phaseolus vulgaris $\mathrm{cv}$. Gallaroy) were grown in a gravelly sandy loam from Talbot (Table 1) and plants were harvested 22 and 33 days after sowing (d.a.s.).

Rates of $\mathrm{Zn}$ applied in solution as $\mathrm{ZnSO}_{4} .7 \mathrm{H}_{2} \mathrm{O}$ were $0,0.17,0.32,0.50,0.75$ and $1.0 \mu \mathrm{g} \mathrm{g}^{-1}$ soil. The times of application were $\mathrm{Zn}$ applied either before (incubated $\mathrm{Zn}$ ) or after (recently applied $\mathrm{Zn}$ ) a 15 day incubation at $40 \pm 1^{\circ} \mathrm{C}$. Each pot was lined with a polyethylene bag and contained $2490 \mathrm{~g}$ of oven-dry soil $(0-10 \mathrm{~cm},<4 \mathrm{~mm})$. Basal nutrients were applied in solution to the soil surface of all pots $\left(\mathrm{mg} \mathrm{pot}^{-1}\right): \mathrm{NH}_{4} \mathrm{NO}_{3}, 214 ; \mathrm{KH}_{2} \mathrm{PO}_{4}, 1757 ; \mathrm{K}_{2} \mathrm{SO}_{4} 328$; $\mathrm{CaCl}_{2}, 441 ; \mathrm{MgSO}_{4} .7 \mathrm{H}_{2} \mathrm{O}, 64 ; \mathrm{MnSO}_{4} . \mathrm{H}_{2} \mathrm{O}, 53 ; \mathrm{CuSO}_{4} .5 \mathrm{H}_{2} \mathrm{O}, 14 ; \mathrm{H}_{3} \mathrm{BO}_{3}, 1 ; \mathrm{CoSO}_{4} .7 \mathrm{H}_{2} \mathrm{O}, 0.86 ;$ $\mathrm{Na}_{2} \mathrm{MoO}_{4} .2 \mathrm{H}_{2} \mathrm{O}, 0 \cdot 8$. Analytical grade reagents were used and macronutrient solutions were purified with dithizone/chloroform (Hewitt 1952). After addition of the nutrient solutions, the soil surface was allowed to dry and the soil was emptied into a large plastic container and mixed, in order of increasing $\mathrm{Zn}$ application, before repotting. Water was added to $75 \%$ of field capacity [field capacity was $25 \%$ gravimetric moisture determined by the column method (Veihmeyer and Hendricksen 1950)] and the pots were covered with a plastic bag, sealed and stored in a constant temperature room at $40 \pm 1^{\circ} \mathrm{C}$ for 15 days. At the end of the incubation, the soil from each pot was emptied onto polyethylene sheeting and dried in a glasshouse for 4 days before repotting into the original liners. The recently applied $\mathrm{Zn}$ treatments and a second application of $\mathrm{P}$ to make a total of $800 \mathrm{mg} \mathrm{P}^{\mathrm{P}} \mathrm{pt}^{-1}$ were added to the soil surface on the day before planting. This rate of $P$ application was shown in a preliminary pot experiment to be adequate but not toxic for the growth of navy beans on this soil. All pots were mixed as previously and repotted. 


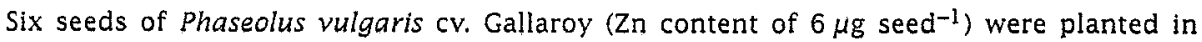
April 1987 and the pots were watered to $60 \%$ of field capacity with double deionized water. The pots were placed in root cooling tanks at $25^{\circ} \mathrm{C}$ and re-randomized weekly on a replicate basis. Pots were watered as required to $60 \%$ of field capacity until 6 d.a.s. when the plants were thinned to three uniform plants per pot. For the remainder of the experiment, the pots were watered to field capacity by weight. Additional $\mathrm{N}\left(214 \mathrm{mg} \mathrm{pot}^{-1}\right.$ of $\mathrm{NH}_{4} \mathrm{NO}_{3}$ ) was added to the pots before watering to weight on $9,17,23$ and 29 d.a.s.

The first harvest was made 22 d.a.s. when plants were cut $2 \mathrm{~cm}$ above the soil level and weighed. The stems were washed with deionized water to remove adhering soil and the plants were sectioned into young leaf, youngest open leaf, youngest fully expanded leaf and remainder of shoots. The parts were wrapped in tissue, placed in envelopes and oven-dried at $60^{\circ} \mathrm{C}$ for $48 \mathrm{~h}$. Plants were harvested in a similar manner 33 d.a.s. The plant samples were digested in $\mathrm{HNO}_{3} / \mathrm{HClO}_{4}$ (Johnson and Ulrich 1959) and $\mathrm{Zn}$ was measured by flame atomic absorption (Allan 1961).

After seedling emergence ( 3 d.a.s.), eight soil cores of $1 \mathrm{~cm}$ diameter were taken from each pot with a stainless steel tube, air-dried and mixed. The soil samples were analysed for DTPA-extractable $\mathrm{Zn}$ (Lindsay and Norvell 1978) and $0.002 \mathrm{M} \mathrm{CaCl}_{2}$-extractable $\mathrm{Zn}$.

\section{Experiment 2. Effect of Incubation on the Chemical Extraction of $\mathrm{Zn}$ from Soils}

Four soils (Table 1) were incubated with $\mathrm{Zn}$ for $0,0.25,0.5,1,2,4$ and 8 days at $40 \pm 1{ }^{\circ} \mathrm{C}$ and analysed for $0.1 \mathrm{M} \mathrm{HCl}$-, EDTA-, DTPA-extractable $\mathrm{Zn}$, and 0.01 and $0.002 \mathrm{M}$ $\mathrm{CaCl}_{2}$-extractable $\mathrm{Zn}$.

Air-dry soil, equivalent to $120 \mathrm{~g}$ of oven-dry soil, was weighed into separate polyethylene bags for each incubation treatment on day 0 and between 13 and $35 \mathrm{ml}$ of $\mathrm{Zn}$ solution was added to each bag to apply $2.5 \mu \mathrm{g} \mathrm{zn} \mathrm{g}^{-1}$ of oven-dry soil and to wet the soil to field capacity. Field capacities were $11,25,21$ and $37 \%$ for soils $1,2,3$ and 4 , respectively. The bags were heat-sealed, mixed thoroughly and placed in an oven at $40^{\circ} \mathrm{C}$ for $0,0.25,0.5$, $1,2,4$ or 8 days. At the end of each incubation period, the bags were removed from the oven and the soil was weighed into polycarbonate vials. Sufficient soil was weighed into each vial so that the oven-dry weight of soil was equivalent to the amount required for the extraction by one of the methods described below. The vials were then frozen until the end of the experiment, when they were thawed to room temperature and extracted in one batch for each soil extraction method. There were three replicates of each treatment.

The methods used for soil analysis were (i) $0.1 \mathrm{M} \mathrm{HCl}$ (Tiller et al. 1972; $30 \mathrm{~min}$ shake at $1: 20$ soil/solution ratio); (ii) $0.005 \mathrm{M} \mathrm{EDTA}$ and $0.01 \mathrm{M} \mathrm{Ca}\left(\mathrm{NO}_{3}\right)_{2}$ (Fujii and Corey 1986); (iii) $0.005 \mathrm{M} \mathrm{DTPA} \mathrm{(Lindsay} \mathrm{and} \mathrm{Norvell} \mathrm{1978);} \mathrm{(iv)} 0.01 \mathrm{M} \mathrm{CaCl}_{2}$; (v) $0.002 \mathrm{M} \mathrm{CaCl}_{2}$. Samples for methods (iv) and (v) were shaken for $16 \mathrm{~h}$ as a soil/solution ratio of $1: 5$. The $\mathrm{CaCl}_{2}$ extracting solutions were prepared from a stock solution that had been purified with dithizone/chloroform. After centrifugation, all extracts were filtered $\left(<0.45 \mu \mathrm{m} ; \mathrm{CaCl}_{2}\right.$ extracts were acidified to $0.1 \mathrm{M}$ with $\mathrm{HCl}$ ) and analysed by flame atomic absorption. Flameless atomic absorption was used when $\mathrm{Zn}$ concentrations were less than $0.1 \mu \mathrm{g} \mathrm{m}^{-1} \mathrm{Zn}$.

Organic carbon was determined by the method of Walkley and Black (1934) with a colorimetric modification (Sims and Haby 1971). The Fe and Al were extracted with acid ammonium oxalate at a soil : solution ratio of $1: 40$ (McKeague and Day 1966) and analysed by atomic absorption (Searle and Daly 1977). Particle-size analysis was determined by the pipette method after shaking soil in a solution of $2.5 \%$ sodium hexametaphosphate in $0.1 \mathrm{~m}$ $\mathrm{NaOH}$ (Gee and Bauder 1986).

\section{Results}

Experiment 1. Effects of Incubation on Plant Growth

(1) Plant symptoms

Symptoms of $\mathrm{Zn}$ deficiency began to appear 15 d.a.s., as faint interveinal chlorosis of the trifoliate leaves of most plants from the nil $\mathrm{Zn}$ treatment and some plants from the $0.17 \mu \mathrm{g} \mathrm{Zn} \mathrm{g}^{-1}$ soil treatments, and became more 
severe with time. Primary leaves of the same plants developed a red-brown colouration of the veins that progressed to water-soaked areas and necrosis. At the second harvest ( 33 d.a.s.), plants from the nil $\mathrm{Zn}$ treatment were stunted and primary leaves had severe red veination with necrotic patches while the first trifoliate leaves were small, droopy and had curled margins. These symptoms are similar to those reported previously (Viets et al. 1954; Boawn et al. 1969; Wade 1985), but red veination, the most obvious symptom on the primary leaves, has not been reported, although Viets et al. (1954) mention brown spots in the mesophyll.

Plants grown with incubated $\mathrm{Zn}$ had more severe symptoms than those grown with recently applied $\mathrm{Zn}$, while symptoms for both times of application decreased in severity as the $\mathrm{Zn}$ rate increased. Plants grown with the highest rate of recently applied $\mathrm{Zn}\left(1 \mu \mathrm{g} \mathrm{Zn} \mathrm{g}^{-1}\right.$ soil) had no symptoms, whereas plants grown with the same amount of incubated $\mathrm{Zn}$ had necrotic areas on the first trifoliate leaves.

(2) Growth and $Z n$ uptake

The application of $\mathrm{Zn}$ increased the dry weight of navy bean shoots at both harvests. At harvest 1 ( 22 d.a.s.), dry weight increased linearly with applied $\mathrm{Zn}$ and there were no consistent differences between the dry weight of plants grown with recently applied and incubated $\mathrm{Zn}$ (Table 2 ). Yield in the absence of applied $\mathrm{Zn}$ was $61 \%$ of the maximum yield obtained when $1 \mu \mathrm{g} \mathrm{Zn} \mathrm{g}^{-1}$ soil was applied. At the second harvest, the dry weight of the recently applied $\mathrm{Zn}$ treatments was consistently higher than that of plants grown with the same amount of incubated $\mathrm{Zn}$, except at the highest $\mathrm{Zn}$ rate $\left(1 \mu \mathrm{g} \mathrm{Zn} \mathrm{g}^{-1}\right.$ soil) where yields were similar (Fig. 1). The concentration of $\mathrm{Zn}$ in the youngest open leaf indicated that maximum yield had been obtained with the highest rate of $\mathrm{Zn}$ addition (Armour et al.; unpublished data). Linear regressions with a common intercept were fitted to the linear part of the response curves (Fig. 1). The relative effectiveness for plant growth, calculated by dividing the slope of the regression for dry weight of shoots against $\mathrm{Zn}$ applied for incubated $\mathrm{Zn}$ by the slope for the regression for recently applied $\mathrm{Zn}$ (Barrow and Campbell 1972), was 0.68 . Plants grown without added $\mathrm{Zn}$ were severely $\mathrm{Zn}$-deficient and the dry weight increased by only $9 \%$ between the two harvests, compared with $256 \%$ for plants grown with the highest $\mathrm{Zn}$ rate.

The $\mathrm{Zn}$ uptake increased linearly with rate of $\mathrm{Zn}$ addition for both recently applied and incubated $\mathrm{Zn}$ applications at harvest 1 (Table 2; $Y=17 \cdot 50+B X, B=33.06$ and 23.59 respectively, $r^{2}=0.86$ ) and harvest 2 (Fig. 2). Relative effectiveness for $\mathrm{Zn}$ uptake (calculated in a similar manner to that for plant growth) was approximately the same for harvests 1 and 2 $(0.71$ and 0.80 , respectively). The ratio of DTPA-Zn extracted from incubated $\mathrm{Zn}$ treatments to that extracted from recently applied $\mathrm{Zn}$ was $0 \cdot 76-0.86$ and was not related to rate of $\mathrm{Zn}$ application (Table 2).

At each harvest, there was also a consistent relationship between dry weight and DTPA- $\mathrm{Zn}$ that was independent of the time of $\mathrm{Zn}$ application. The relationship was linear at harvest $1\left(r^{2}=0.83\right)$, but better explained by a Mitscherlich relationship at harvest 2 (Fig. 3). Concentrations of $\mathrm{Zn}$ in $0.002 \mathrm{M}$ $\mathrm{CaCl}_{2}$ extracts were close to the concentrations in the blank solution and could not be measured. 
Table 2. Dry weight and $\mathrm{Zn}$ uptake of navy bean shoots and DTPA-Zn for recently applied and incubated $\mathrm{Zn}$ applications for harvest 1 ( 22 d.a.s., experiment 1 )

\begin{tabular}{|c|c|c|c|c|c|c|c|}
\hline \multirow[t]{2}{*}{$\begin{array}{l}\text { Zn rate } \\
\left(\mu \mathrm{g} \mathrm{g}^{-1}\right)\end{array}$} & \multicolumn{2}{|c|}{$\begin{array}{c}\text { Dry weight of shoots } \\
\left.(\mathrm{g} \mathrm{pot})^{-1}\right)\end{array}$} & \multicolumn{2}{|c|}{$\begin{array}{l}\text { Zn uptake } \\
\left(\mu \text { g pot }^{-1}\right)\end{array}$} & \multicolumn{2}{|c|}{$\begin{array}{l}\text { DTPA-Zn } \\
\left(\mu \mathrm{g} \mathrm{g}^{-1}\right)\end{array}$} & \multirow{2}{*}{$\begin{array}{c}\text { Relative } \\
\text { concentration } \\
\text { of DTPA- } \mathrm{Zn}^{\mathrm{B}}\end{array}$} \\
\hline & Recent $^{A} \mathrm{Zn}$ & Incubated $\mathrm{Zn}$ & Recent $\mathrm{Zn}$ & Incubated $\mathrm{Zn}$ & Recent $\mathrm{Zn}$ & Incubated $\mathrm{Zn}$ & \\
\hline 0 & $2 \cdot 04$ & $2 \cdot 04$ & $18 \cdot 3$ & $18 \cdot 3$ & 0.07 & 0.07 & \\
\hline 0.17 & $2 \cdot 23$ & $2 \cdot 08$ & $24 \cdot 5$ & $19 \cdot 0$ & $0 \cdot 10$ & 0.08 & 0.81 \\
\hline 0.32 & $2 \cdot 10$ & $2 \cdot 50$ & $23 \cdot 2$ & $25 \cdot 7$ & 0.11 & 0.09 & 0.76 \\
\hline 0.50 & $2 \cdot 73$ & $2 \cdot 75$ & $42 \cdot 3$ & $32 \cdot 3$ & $0 \cdot 14$ & 0.11 & 0.81 \\
\hline 0.75 & $2 \cdot 97$ & $2 \cdot 36$ & $37-8$ & $31 \cdot 1$ & $0 \cdot 18$ & $0 \cdot 14$ & 0.80 \\
\hline $1 \cdot 00$ & $3 \cdot 44$ & $3 \cdot 23$ & $51 \cdot 3$ & $43 \cdot 4$ & 0.23 & 0.21 & 0.86 \\
\hline
\end{tabular}

A Recently applied $\mathrm{Zn}$.

B Incubated DTPA-Zn/Recently applied DTPA-Zn.

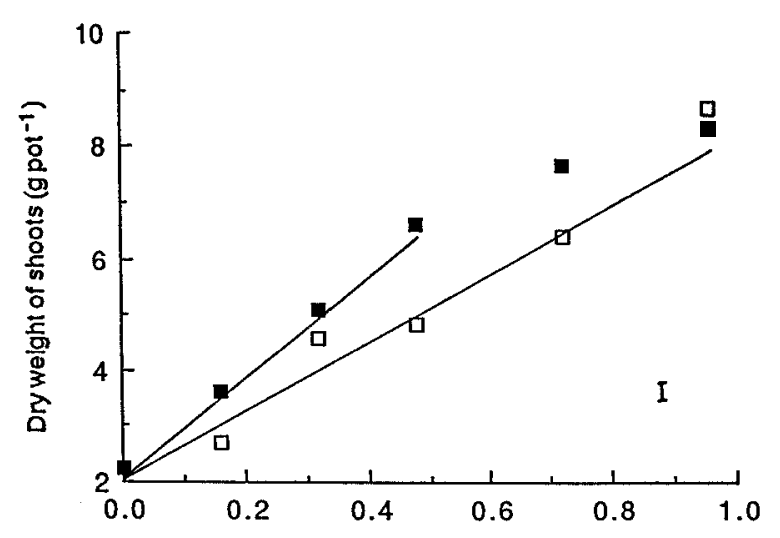

Fig. 1. Effect of recently applied (a) and incubated ( $\square$ ) $\mathrm{Zn}$ applications on the dry weight of navy bean shoots at harvest 2 (experiment 1 ) and fitted linear regressions of $Y=A+B X$, where $A=2.04$ and $r^{2}=0.97, B=9.33$ for recently applied $\mathrm{Zn}$ and 6.34 for incubated $\mathrm{Zn}$. The vertical bar denotes the standard error.

Zn applied $\left(\mu \mathrm{g} \mathrm{g}^{-1}\right)$ 


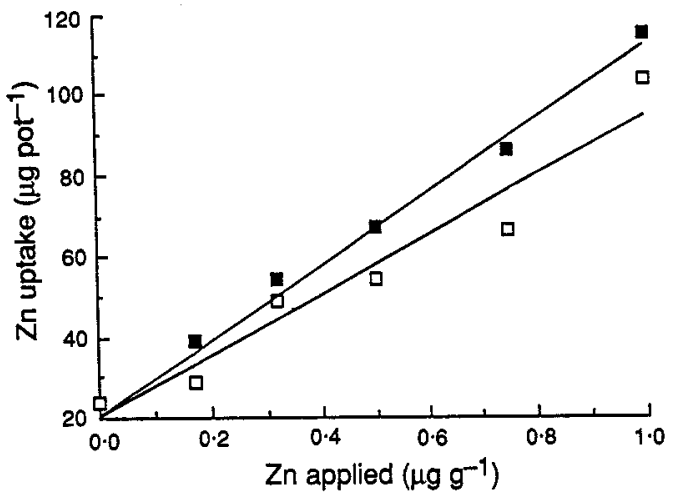

Fig. 2. Effect of recently applied ( $\mathbf{m})$ and incubated (ㄷ) $\angle \mathrm{n}$ applications on $\mathrm{Zn}$ uptake by navy bean shoots at harvest 2 and fitted linear regressions of $Y=A+B X$, where $A=20.55$ and $r^{2}=0.97, B=93.23$ for recently applied $\mathrm{Zn}$ and 74.73 for incubated $\mathrm{Zn}$.

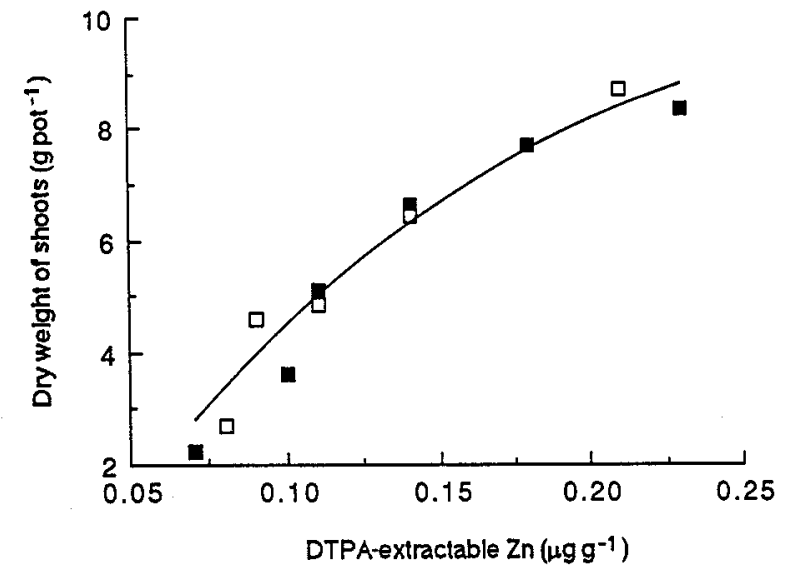

Fig. 3. Relationship between dry weight of navy bean shoots at harvest 2 and DTPA-extractable $\mathrm{Zn}$ for recently applied $(\mathbf{\omega})$ and incubated $(\square) \mathrm{Zn}$ applications, and fitted Mitscherlich curve, $Y=11 \cdot 82-14 \cdot 43 \mathrm{e}^{-6.75 x}, r^{2}=0.86$ (experiment 1 ).

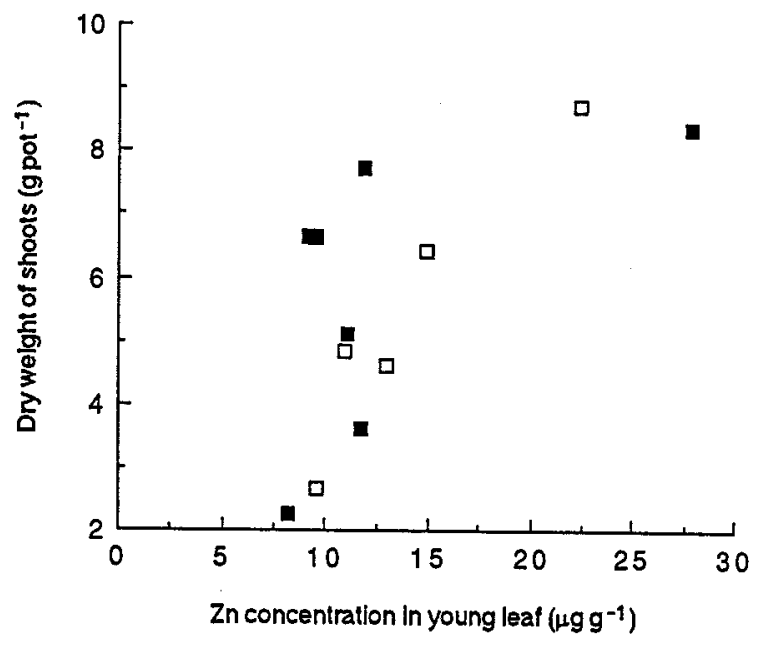

Fig. 4. Relationship between dry weight of navy bean shoots at harvest 2 and $\mathrm{Zn}$ concentrations in young leaves for recently applied ( $\boldsymbol{(})$ and incubated ( $\square$ ) $\mathrm{Zn}$ applications (experiment 1). 
Table 3. Zinc concentration on an oven-dry basis in untreated soil and after the addition of $2 \cdot 5 \mu \mathrm{g} \mathrm{Zn}^{-1}$ soil measured by five chemical extractants (experiment 2)

\begin{tabular}{|c|c|c|c|c|c|c|c|c|c|c|}
\hline \multirow[t]{2}{*}{$\begin{array}{l}\text { Soil } \\
\text { No. }\end{array}$} & \multicolumn{2}{|c|}{$\begin{array}{c}\mathrm{HCl} \\
\left(\mu \mathrm{g} \mathrm{g}^{-1}\right)\end{array}$} & \multicolumn{2}{|c|}{$\begin{array}{c}\text { EDTA } \\
\left(\mu \mathrm{g} \mathrm{g}^{-1}\right)\end{array}$} & \multicolumn{2}{|c|}{$\begin{array}{c}\text { DTPA } \\
\left(\mu \mathrm{g} \mathrm{g}^{-1}\right)\end{array}$} & \multicolumn{2}{|c|}{$\begin{array}{c}0.01 \mathrm{M} \mathrm{CaCl}_{2} \\
\left(\mu \mathrm{g} \mathrm{kg}^{-1}\right)\end{array}$} & \multicolumn{2}{|c|}{$\begin{array}{c}0.002 \mathrm{M} \mathrm{CaCl}_{2} \\
\left(\mu \mathrm{g} \mathrm{kg}^{-1}\right)\end{array}$} \\
\hline & Untreated & Fert $^{A}$ & Untreated & Fert. & Untreated & Fert. & Untreated & Fert. & Untreated & Fert. \\
\hline 1 & 0.07 & $2 \cdot 25$ & 0.04 & $2 \cdot 21$ & 0.03 & $1 \cdot 87$ & $6 \cdot 5$ & $\begin{array}{c}1580 \\
(1320-1795)^{\mathrm{B}}\end{array}$ & $2 \cdot 0$ & $\begin{array}{c}1176 \\
(950-1420)\end{array}$ \\
\hline 2 & 0.27 & $2 \cdot 45$ & 0.13 & $2 \cdot 06$ & 0.07 & $1 \cdot 20$ & $<2$ & $\begin{array}{c}11 \cdot 0 \\
(8 \cdot 5-15 \cdot 0)\end{array}$ & $<2$ & $\begin{array}{c}8 \cdot 8 \\
(7 \cdot 9-11 \cdot 1)\end{array}$ \\
\hline 3 & 0.83 & $2 \cdot 80$ & 0.61 & $2 \cdot 60$ & 0.39 & $1 \cdot 78$ & $<2$ & $<2$ & - & - \\
\hline 4 & $1 \cdot 95$ & $3 \cdot 13$ & 0.90 & $1 \cdot 36$ & $0 \cdot 73$ & $1 \cdot 37$ & $3 \cdot 0$ & $\begin{array}{c}24 \cdot 5 \\
(19 \cdot 5-30 \cdot 5)\end{array}$ & $4 \cdot 3$ & $\begin{array}{c}8 \cdot 3 \\
(7 \cdot 5-9 \cdot 7)\end{array}$ \\
\hline s.e. & 0.02 & 0.24 & 0.02 & 0.13 & 0.02 & 0.12 & $0 \cdot 33$ & 80 & 0.35 & 79 \\
\hline
\end{tabular}

A $\mathrm{Zn}$ concentration at the first incubation time of 0.03 days at $40^{\circ} \mathrm{C}$.

B Range of replicate data.

Table 4. Coefficients and $\boldsymbol{r}^{2}$ for the regression of the relative concentration of Zn extracted by five methods with time of incubation for the model $Y=C t^{B}$ (experiment 2)

\begin{tabular}{|c|c|c|c|c|c|c|c|c|c|c|c|c|c|c|c|}
\hline \multirow[t]{2}{*}{ Soil } & \multicolumn{3}{|c|}{$\mathrm{HCl}$} & \multicolumn{3}{|c|}{ EDTA } & \multicolumn{3}{|c|}{ DTPA } & \multicolumn{3}{|c|}{$0.01 \mathrm{M} \mathrm{CaCl}_{2}$} & \multicolumn{3}{|c|}{$0.002 \mathrm{M} \mathrm{CaCl}_{2}$} \\
\hline & $B$ & $C$ & $r^{2}$ & $B$ & $c$ & $r^{2}$ & $B$ & $C$ & $r^{2}$ & $B$ & C & $r^{2}$ & $B$ & C & $r^{2}$ \\
\hline 1 & -0.060 & 0.733 & $0.77^{*}$ & -0.066 & 0.696 & $0.96^{* *}$ & $-0 \cdot 124$ & 0.473 & $0.98^{* *}$ & $-0 \cdot 117$ & 0.413 & $0.95^{* *}$ & $-0 \cdot 144$ & 0.274 & $0.94^{*}$ \\
\hline 2 & $-0 \cdot 181$ & 0.459 & $0.88^{* *}$ & $-0 \cdot 230$ & $0 \cdot 345$ & $0.97^{* *}$ & $-0 \cdot 337$ & $0 \cdot 143$ & $0 \cdot 97^{* *}$ & $-0 \cdot 340$ & 0.001 & $0 \cdot 89^{* *}$ & $-0 \cdot 271$ & 0.001 & $0.87^{*}$ \\
\hline 3 & -0.025 & 0.710 & $0.79^{* *}$ & -0.041 & $0 \cdot 732$ & $0.66^{*}$ & -0.072 & 0.441 & $0 \cdot 88^{* *}$ & & & & & & \\
\hline 4 & $-0 \cdot 327$ & 0.177 & $0 \cdot 90^{* *}$ & -0.546 & 0.047 & $0 \cdot 70^{*}$ & $-0 \cdot 713$ & 0.029 & $0.76^{*}$ & -0.695 & 0.001 & $0 \cdot 80^{* *}$ & & & \\
\hline
\end{tabular}

* $P<0.05 ; * * P<0.01$. 
Incubation did not appear to affect the relationship between dry weight and the $\mathrm{Zn}$ concentration in plant tissue at each harvest (Fig. 4; harvest 1 data not presented).

\section{Experiment 2. Effect of Incubation on the Chemical Extraction of $\mathrm{Zn}$ from Soils}

The addition of $2.5 \mu \mathrm{g} \mathrm{Zn} \mathrm{g}^{-1}$ soil increased the concentration of $\mathrm{Zn}$ extracted by each method at all times of incubation compared with concentrations of the untreated soil (Table 3 ). The largest increases in $\mathrm{Zn}$ concentration after the addition of $\mathrm{Zn}$ occurred in the $\mathrm{CaCl}_{2}$ extracts and the smallest increases were generally in DTPA.
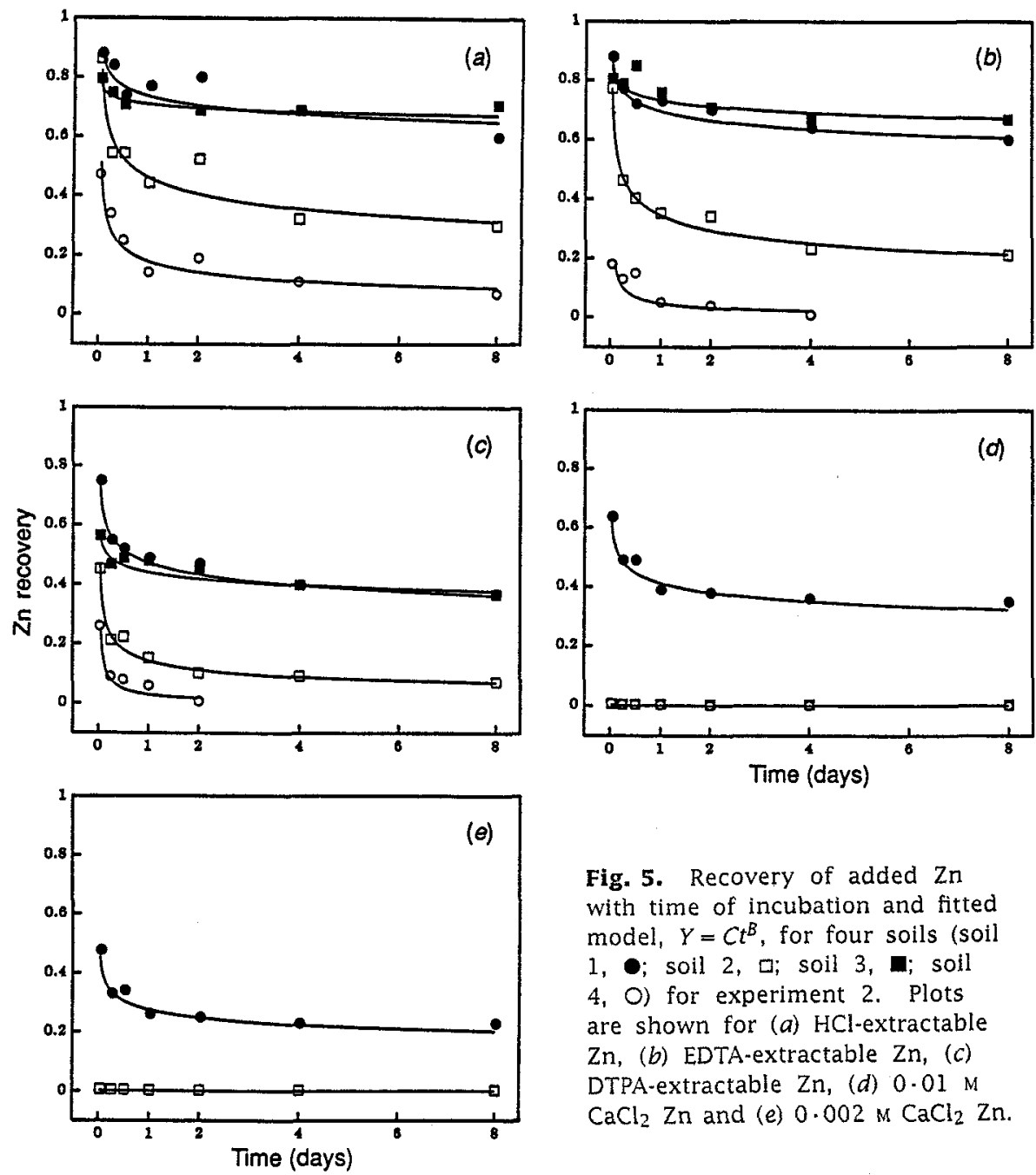

Fig. 5. Recovery of added $\mathrm{Zn}$ with time of incubation and fitted model, $Y=C t^{B}$, for four soils (soil 1 , soil 2, घ; soil 3 , a; soil 4, O) for experiment 2 . Plots are shown for (a) $\mathrm{HCl}$-extractable $\mathrm{Zn}$, (b) EDTA-extractable $\mathrm{Zn},(c)$ DTPA-extractable $\mathrm{Zn},(d) 0.01 \mathrm{M}$ $\mathrm{CaCl}_{2} \mathrm{Zn}$ and (e) $0.002 \mathrm{M} \mathrm{CaCl}_{2} \mathrm{Zn}$

In all soils, the $\mathrm{Zn}$ concentration in each extract decreased exponentially with increasing time of incubation, indicating that none of the extractants are a measure of the total $\mathrm{Zn}$ concentration of the soil. The extent and rate of the decrease differed between soils and extractants. For each soil and extractant, a recovery of $\mathrm{Zn}$ was calculated by the formula, $\{[\mathrm{Zn}]$ extracted $-[\mathrm{Zn}]$ native $\} / 2 \cdot 5$, 
where $2.5 \mu \mathrm{g} \mathrm{Zn} \mathrm{g}^{-1}$ was the rate of $\mathrm{Zn}$ addition to the soil (Fig. 5). We assumed that incubation of the soil did not affect the extractability of native $\mathrm{Zn}$. On average, between $50 \%$ and $77 \%$ of the added $\mathrm{Zn}$ was recovered by DTPA, EDTA and $\mathrm{HCl}$ extractants at the first incubation time. In contrast, the recovery by the $\mathrm{CaCl}_{2}$ solutions was very low $(<1 \%)$ in soils 2 and 4 but high in soil 1 (49-63\%). Data from soil 3 were excluded because of the inability to obtain a clear extract with $0.002 \mathrm{M} \mathrm{CaCl}_{2}$ and erratic results for $0.01 \mathrm{M} \mathrm{CaCl}_{2}$.

The model, $Y=C t^{B}$, was used to describe the relationship between $\mathrm{Zn}$ recovery and time of incubation. The time between the addition of $\mathrm{Zn}$ to the soil and the freezing of the samples was calculated by the Arrhenius equation (Castellan 1970) to be equivalent to 0.03 days at $40^{\circ} \mathrm{C}$ and this was used for the first incubation time in the model (Fig. 5). For soil 4 , the concentration of $\mathrm{Zn}$ extracted at incubation times of 4 and 8 days for DTPA and at 8 days for EDTA was not different to the concentrations in virgin soil so the model was truncated at incubation times of 2 and 4 days for DTPA and EDTA, respectively, for this soil. The model generally provided a good fit to the data (Table 4) and most coefficients of determination were significant at $P<0.01$, but it was not fitted to data for $0.002 \mathrm{M} \mathrm{CaCl}_{2}$ for soil 4 because of the very low recovery at all incubation times. The coefficient, $C$, is a measure of the recovery of $\mathrm{Zn}$ after 1 day of incubation and the recovery increased with increasing $C$. Coefficient $B$ is an estimate of the rate of decrease of $Y$; this rate increased as $B$ decreased.

Of the $\mathrm{HCl}$, EDTA and DTPA extractants, $\mathrm{HCl}$ had the highest $C$ and $B$ coefficients, DTPA had the lowest and EDTA was usually intermediate. For these extractants, $C$ values were in the order of soil $4 \ll$ soil $2 \ll$ soil 3 , soil 1. The $B$ coefficients for all extractants were in the order soil $4<$ soil $2<$ soil $1<$ soil 3 , indicating that the greatest rate of decrease occurred in soil 4 .

Another model, $Y=(1+K t)^{-B}$ (Barrow 1980), was also fitted to the data. However, because this model requires the initial $\mathrm{Zn}$ concentration to be set at 1 , the large differences between the soils and extractants in the recovery for this incubation time were not obvious.

\section{Discussion}

Incubation of applied $\mathrm{Zn}$ with the soil decreased both the availability of $\mathrm{Zn}$ to navy beans and the quantity of $\mathrm{Zn}$ extracted by the five soil extractants. The decrease in availability appeared to be caused by continuing reactions within the soil that converted some of the applied $\mathrm{Zn}$ into a form that is unavailable for plant uptake. The rate of the reaction as measured by experiment 2 was rapid initially, with a maximum of $87 \%$ of the added $\mathrm{Zn}$ recovered after the first incubation period of 0.03 days, and then continued more slowly for up to 8 days (Fig. 5).

There were different rates of decline of $\mathrm{Zn}$ recovery in the four soils and between the different extractants used in the laboratory experiment. Comparisons of the 'instant' recoveries of added $\mathrm{Zn}$ by $\mathrm{HCl}$, EDTA and DTPA in the soils at the incubation time of 0.03 days show that the reaction of $\mathrm{Zn}$ with the soil was more rapid in soil 4 than in the other soils (Table 3 ). The reactions would have occurred during the period between the addition of $2.5 \mu \mathrm{g} \mathrm{Zn} \mathrm{g}^{-1}$ soil and when the samples were frozen after weighing. The low recovery of $\mathrm{Zn}$ at all incubation times from soil 4 for all extractants may 
be due to the high clay, silt, $\mathrm{Al}$ and Fe content of the soil. The recoveries for soil 2 had the next greatest rate of decrease and the difference in $B$ and $C$ coefficients for this soil compared with soils 1 and 3 may be due to the high organic carbon content and the comparatively high extractable Al concentration. The relationship between the soil organic fraction and cations has two contrasting effects. On one hand, soluble organic compounds may complex $\mathrm{Zn}$ and increase its concentration in the soil solution and its transport to roots, while insoluble organic compounds may act as a sink for these ions (Stevenson 1982; Chairidchai and Ritchie 1989).

Variation in the rate of decline of the recovery of $\mathrm{Zn}$ (i.e. the $B$ coefficient) could reflect the number of sites available for adsorption. However, there were no consistent relationship between $B$ and soil properties that is considered to be related to the ability of soil to adsorb nutrients. The lack of correlation could be due to the small sample size of four soils. Brennan and Gartrell (1986) were unable to relate different rates of decline in the availability of $\mathrm{Zn}$ to sub-clover with differences in $\mathrm{pH}, \mathrm{CEC}$, organic carbon, clay, $\mathrm{Zn}$ or free sesquioxides in 53 Western Australian, Queensland, South Australian and Victorian soils.

The extent of decline of the recovery of $\mathrm{Zn}$ was greatest for the intensity measures of available $\mathrm{Zn}\left(0.002\right.$ and $\left.0.01 \mathrm{M} \mathrm{CaCl}_{2}\right)$ and smallest in the quantity measure that extracted the most $\mathrm{Zn}(0.1 \mathrm{M} \mathrm{HCl})$.

The common relationships in experiment 1 , for dry weight of shoots as a function of DTPA- $\mathrm{Zn}$ and for dry weight versus plant $\mathrm{Zn}$ concentrations for the recently applied and incubated $\mathrm{Zn}$ treatments (Fig. 3 and Fig. 4), are an important result. These relationships, and the similar dry weights at harvest 2 for both times of $\mathrm{Zn}$ application at close to maximum growth ( $1 \mu \mathrm{g} \mathrm{Zn} \mathrm{g}^{-1}$ soil), show that the effects of incubating the soil in experiment 1 on plant growth were confined to reducing the availability of the added $\mathrm{Zn}$.

The lack of effect of incubation on dry weight of shoots for harvest 1 may have been due to variability in the early stages of plant growth (reflecting the influence of seed size and vigor) or to a lower demand for $\mathrm{Zn}$ compared with harvest 2 . The $\mathrm{Zn}$ uptake was clearly reduced by incubation for harvest 1. In other studies with copper, Brennan et al. (1980) also reported that similar estimates of relative effectiveness of incubated copper were obtained for dry matter production and copper uptake although, as in this work, the relative effectiveness for plant growth was slightly lower than that for copper uptake.

For a particular soil, if the major factor affecting the availability of recently applied $\mathrm{Zn}$ is reactions that continue to convert the $\mathrm{Zn}$ into an unavailable form, then a useful characteristic of the soil test (apart from a uniform relationship with plant growth and nutrient uptake) would be a large decrease with time. However, a good correlation between the two parameters is not necessarily sufficient because the shape of the relationship can affect the accuracy of the prediction. Large changes in the values of a potential soil test are a good characteristic because the variation of plant growth with the soil test will tend to be gradual and therefore will make more accurate predictions of availability than a relationship where plant growth varies enormously with a small change in the value of the soil test. The results from experiment 1 indicated that at lower rates of $\mathrm{Zn}$ addition $\left(<1 \mu \mathrm{g} \mathrm{g} \mathrm{g}^{-1}\right.$ soil), even though the change in $\mathrm{Zn}$ 
extracted by $0.002 \mathrm{M} \mathrm{CaCl}_{2}$ may have been large, the absolute values are very small and close to or below the detection limit for $\mathrm{Zn}$ analyses and therefore prone to large errors. The $\mathrm{Zn}$ extracted by the quantity estimates of available $\mathrm{Zn}$ were all within the detection range of the analytical method.

Incubated $\mathrm{Zn}$ in experiment $\mathrm{I}$ appeared to be more available to plants than would be anticipated from the changes of DTPA- $Z n$ with time in experiment 2. In experiment $1, \mathrm{Zn}$ extracted by DTPA after 15 days incubation at $40^{\circ} \mathrm{C}$ was $80 \%$ of $\mathrm{Zn}$ extracted by DTPA from the soils containing recently applied $\mathrm{Zn}$. In comparison, DTPA-Zn in the same soil in experiment 2 decreased rapidly so that $Z n$ extracted after 8 days was only $15 \%$ of that at the initial incubation period of 0.03 days. However, the comparison in experiment 1 was made between $\mathrm{Zn}$ extracted after 15 days of incubation and the equivalent of 0.75 days incubation at $40^{\circ} \mathrm{C}$ (as this was the period between the addition of the recently applied $\mathrm{Zn}$ and collection of soil samples). The results of experiment 2 (Fig. $5 \mathrm{c}$ ) showed that the decreases in DTPA-Zn in the first 0.75 days of incubation were substantial and far greater than the decrease in DTPA- $\mathrm{Zn}$ at times after 0.75 days. In experiment 1 , most of the change in extractability of $\mathrm{Zn}$ would have occurred before the plants were grown (and the soils were analysed) and, hence, incubated $\mathrm{Zn}$ was only slightly less available than recently applied $\mathrm{Zn}$. There were also different rates of $\mathrm{Zn}$ addition in the two experiments. Additions of $\mathrm{Zn}$ were a maximum of $1.3 \mu \mathrm{g} \mathrm{Zn} \mathrm{g}^{-1}$ soil in experiment 1 (adjusted from $1.0 \mu \mathrm{g} \mathrm{g}^{-1}$ to allow for incubation at $75 \%$ of field capacity compared with $100 \%$ in experiment 2 ) and $2 \cdot 5 \mu \mathrm{g} \mathrm{g}^{-1}$ in experiment 2. Barrow (1986) has shown, during the reaction of $\mathrm{Zn}$ with soil, that the amount of $\mathrm{Zn}$ retained in the soil increases with increasing solution $\mathrm{Zn}$ concentration.

In conclusion, the availability of $\mathrm{Zn}$ to navy beans and the concentration of $\mathrm{Zn}$ measured in a range of chemical extractants both decreased when $\mathrm{Zn}$ was incubated with the soil for a relatively short period of time. The rate and extent of the decrease in the extractant varied widely with soil type.

\section{Acknowledgments}

The senior author completed this research while on Study Leave from the Queensland Department of Primary Industries. We thank Mr W. J. Simmons and Mr K. Snowball for technical advice.

\section{References}

Allan, J. E. (1961). The determination of zinc in agricultural materials by atomic absorption spectrophotometry. Analyst 86, 531-4.

Barrow, N. J. (1980). Evaluation and utilization of residual phosphorus in soils. In 'The Role of Phosphorus in Agriculture'. (Eds F. E. Khasawneh, E. C. Sample and E. J. Kamprath.) pp. 333-59. (ASA-CSSA-SSSA: Madison.)

Barrow, N. J, (1986). Testing a mechanistic model. IV. Describing the effects of pH on zinc retention by soils. J. Soil Sci. 37, 295-302.

Barrow, N. J., and Campbell, N. A. (1972). Methods of measuring residual value of fertilizers. Aust. J. Exp. Agric. Anim. Husb. 12, 502-10.

Boawn, L. C., Rasmussen, P. E., and Brown, J. W. (1969). Relationship between tissue zinc levels and maturity period of field beans. Agron. J. 61, 49-51.

Brennan, R. F., and Gartrell, J. W. (1986). Correction of pastures deficient in zinc for sheep. Western Aust. Dept. Agric. Div. of Plant Res. Tech. Rep. No. 2.

Brennan, R. F., Gartrell, J. W., and Robson, A. D. (1980). Reactions of copper with soil affecting its availability to plants. I. Effect of soil type and time. Aust. J. Soil Res. 18, 447-59. 
Brennan, R. F., and MCGrath, J. F. (1988). The vertical movement of zinc on sandy soils in southern Western Australia. Aust. J. Soil Res. 26, 211-16.

Castellan, G. W. (1970). 'Physical Chemistry.' p. 607. (Addison-Wesley: Massachusetts.)

Chairidchai, P., and Ritchie, G. S. P. (1989). Zinc absorption by a lateritic soil in the presence of organic ligands. Soil Sci. Soc. Am. J. (in press).

Donald, C. M., and Prescott, J. A. (1975). Trace elements in Australian crop and pasture production. In 'Trace elements in Soil-Plant-Animal Systems'. pp. 7-38. (Academic Press: New York.)

Gee, G. W., and Bauder, J. W. (1986). Particle size analysis. In 'Methods of Soil Analysis. Part 1: Physical and Mineralogical Methods'. pp. 383-411. 2nd Edn. Agronomy Monograph No. 9. (Am. Soc. Agron.: Madison.)

Fujil, R., and Corey, R. B. (1986). Estimation of isotopically exchangeable cadmium and zinc in soils. Soil Sci. Soc. Am. J. 50, 306-8.

Hewitt, E. J. (1952). Sand and water culture methods used in the study of plant nutrition. Tech. Commun. Commonw. Bur. Hortic. Plant Crops No. 22.

Johnson, C. M., and Ulrich, A. (1959). Analytical methods for use in plant analysis. Bull. Calif. Agric. Exp. Stn No. 766.

Lindsay, W. L., and Norvell, W. A. (1978). Development of a DTPA soil test for zinc, iron, manganese and copper. Soil Sci. Soc. Am. J. 42, 421-8.

McKeague, J. A., and Day, J. H. (1966). Dithionite- and oxalate-extractable Fe and Al as aids in differentiating various classes of soils. Can. J. Soil. Sci. 46, 13-22.

Mengel, L., and Kirkby, E. A. (1978). 'Principles of Plant Nutrition.' p. 260. (International Potash Institute: Bern.)

Northcote, K. H. (1974). 'A Factual Key for the Recognition of Australian Soils.' (Rellim Technical Publications: Glenside, S.A.)

Searle, P. L., and Daly, B. K. (1977). The determination of aluminium, iron, manganese and silicon in acid oxalate soil extracts by flame emission and atomic absorption spectrometry. Geoderma 19, 1-10.

Sims, J. R., and Haby, V. A. (1971). Simplified colorimetric determination of soil organic matter. Soil Sci. 112, 137-41.

Stevenson, F. J. (1982). 'Humus Chemistry.' pp. 337-54. (John Wiley: New York.)

Tiller, K. G., Honeysett, J. L., and DeVries, M. P. C. (1972). Soil zinc and its uptake by plants. I1. Soil chemistry in relation to prediction of availability. Aust. J. Soil Res. 10, 165-82.

Trierweiler, J. F., and Lindsay, W. L. (1969). EDTA-ammonium carbonate soil test for zinc. Soil Sci. Soc. Am. Proc. 33, 49-54.

Veihmeyer, F. J., and Hendricksen, A. H. (1950). Soil moisture in relation to plant growth. Ann. Rev. Plant Physiol. 1, 285-304.

Viets, F. G., Boawn, L. C., and Crawford, C. L. (1954). Zinc content of bean plants in relation to deficiency symptoms and yield. Plant Physiol. 29, 76-9.

Wade, L. J. (1985). Zinc deficiency in navy beans in the Dawson-Callide. 1. Diagnosis of the disorder. Qld J. Agric. Anim. Sci. 42, 57-62.

Walkley, A., and Black, 1. A. (1934). An examination of the Degtjareff method for determining soil organic matter, and a proposed modification of the chromic acid titration method. Soil Sci. 37, 29-38. 